\title{
Effects of Pyrite Texture on Flotation Performance of Copper Sulfide Ores
}

\author{
İlkay B. Can *®D, Seda Özçelik and Zafir Ekmekçi \\ Department of Mining Engineering, Hacettepe University, Beytepe, Ankara 06800, Turkey; \\ sedaozcelik26@gmail.com (S.Ö.); e.zafir@gmail.com (Z.E.) \\ * Correspondence: ilkay@hacettepe.edu.tr
}

Citation: Can, İ.B.; Özçelik, S.;

Ekmekçi, Z. Effects of Pyrite Texture on Flotation Performance of Copper Sulfide Ores. Minerals 2021, 11, 1218. https://doi.org/10.3390/min11111218

Academic Editors: Herbert Pöllmann and Uwe König

Received: 18 October 2021

Accepted: 28 October 2021

Published: 1 November 2021

Publisher's Note: MDPI stays neutral with regard to jurisdictional claims in published maps and institutional affiliations.

Copyright: (C) 2021 by the authors. Licensee MDPI, Basel, Switzerland. This article is an open access article distributed under the terms and conditions of the Creative Commons Attribution (CC BY) license (https:// creativecommons.org/licenses/by/ $4.0 /)$.

\begin{abstract}
Pyrite particles, having framboidal/altered texture, are known to significantly affect pulp chemistry and adversely affect flotation performance. Therefore, the main objectives of this study were to demonstrate influence of pyrite mineralogy on the flotation of copper (sulphidic) ores and develop alternative conditions to improve the performance. Two copper ore samples (Ore A and Ore B) having different textural/modal mineralogy and flotation characteristics were taken from different zones of the same ore deposit. Ore B contained framboidal pyrite and altered pyrite/marcasite, which is considered the main reason for the low flotation performance in both copper and pyrite flotation sections of the process plant. Flotation tests were conducted under different conditions using the two ore samples and a 50:50 blend. The results showed that Ore A could be concentrated under the base conditions, as applied in the existing flotation plant. On the other hand, Ore B did not respond to the base conditions and a copper recovery of only $5 \%$ could be obtained. Besides, blending Ore B with Ore A negatively affected the flotation behavior of Ore A. An alternative flotation chemistry was applied on Ore B using $\mathrm{Na}_{2} \mathrm{~S}$ for surface cleaning and Na-Metabisulfite (MBS) for pyrite depression in the copper flotation stage. The surface cleaning reduced the rate of oxidation of the framboidal pyrite in Ore B. As a result, the copper recovery could be increased to $52 \% \mathrm{Cu}$ for Ore B, and $65 \%$ for the mixed ore sample.
\end{abstract}

Keywords: framboidal pyrite; sulfide minerals; flotation; process mineralogy

\section{Introduction}

Pyrite $\left(\mathrm{FeS}_{2}\right)$ is the most abundant sulfide mineral and usually occurs both as a primary and secondary mineral according to its genesis. Lattice substitution of some minor and trace elements such as nickel, cobalt, arsenic, lead, and gold are also the results of this ore genesis and geographical location [1] and may have an impact on pyrite floatability [2]. Pyrite is widespread in hydrothermal veins, modern and ancient sedimentary (volcano, exhalative) rocks, contact metamorphic deposits/rocks and as an accessory mineral in igneous rocks [3]. The genesis of pyrite has been considered as one of the main causes of variation in surface chemical characteristics and, thereby, of the differences in their floatability [4]. Contact angle measurements of different types of pyrite showed a significant relationship between the origin of pyrite and its wetting characteristics. Flotation characteristics of pyrite are also influenced by morphology, crystallography, and the presence of impurities in the crystal structure [5]. The marcasite mineral $\left(\mathrm{FeS}_{2}\right)$, the polymorph of pyrite, has different crystallography and stability and, hence, different flotation behaviour than that of pyrite, even when they exist in same deposits [3,6].

Pyrite has a simple cubic crystal structure, while marcasite, which has the same chemical composition as pyrite, has an orthorhombic crystal structure [7]. Another micromorphological feature, called framboid, is also described for pyrite. Framboidal form of pyrite can be defined as raspberry-shaped masses. This spherical structure is composed of numerous microcrystals, which are equant and equidimensional [8]. This microcrystal packing is typically irregular and disordered. A framboidal morphology of pyrite is one 
of the common ore textures observed in disseminated massive sulfide ore deposits [9]. It is also ubiquitous in modern sediments and ancient sedimentary rocks but occurs less frequently in hydrothermal deposits [10].

Oxidation of pyrite produces hydroxide/oxide coating products which have significant effects on floatability and associated minerals. The rate of surface oxidation varies as a function of pulp chemistry, the grinding conditions and mineralogical characteristics. For example, marcasite $\left(\mathrm{FeS}_{2}\right)$ is more reactive than pyrite and reacts more readily with moisture and oxygen [11,12]. Relative reaction rates for different morphological forms of pyrite are described in the order of marcasite $>$ framboidal pyrite $>$ massive pyrite [13]. The stabilities of these minerals are different, and framboidal pyrite decomposes more readily under mildly oxidizing conditions than cubic pyrite [14]. Thus, it can be said that different crystalline pyrite forms would react differently to mild oxidation conditions during flotation. Miller et al. [15] observed the same finding for reactive auriferous pyrite. Air was replaced by nitrogen gas to remove the dissolved oxygen from the flotation system and thereby auriferous pyrite oxidation could be minimized [16], particularly for framboidal pyrite and marcasite.

It is known that selective flotation of the base metal sulfide minerals from pyrite is strongly influenced by the type and concentration of metal oxidation species produced during grinding [17]. These species may affect the floatability of minerals, rendering the surfaces hydrophilic or leading to inadvertent activation $[18,19]$. The pyrite content of the flotation feed also plays an important role in increasing the oxidation of minerals as it consumes dissolved oxygen in the flotation pulp [20]. Since the framboidal pyrite has a large surface area, the oxidation rate is faster than with the standard texture of pyrite, producing a variety of iron oxidation products. It has been proposed that the presence of framboidal pyrite in an ore is a critical parameter affecting $\mathrm{Pb}$ flotation rather than the high amount of purely pyrite, since it increases the rate of galvanic interaction with other metal sulfides [5].

Pyrite is the most common of the gold-bearing minerals and, therefore, pyrite morphology is of paramount importance for its association with gold. Submicroscopic association with framboidal pyrite is one of the main textures observed in gold deposits [21]. Simmons [14] reported that the occurrence of gold in auriferous pyrite may differ, as relatively low levels of gold were detected in coarse grained pyrites, whereas fine grained, amorphous and framboidal pyrite contained much higher levels of gold. In other words, the framboidal structure of pyrite may have the highest intrinsic gold value. However, significant amounts of gold loss to tailing may occur due to the problems in floatability of fine grained, framboidal pyrite particles.

Similar effects are also observed in leaching gold from pyrite particles. The pyrite source is an important parameter in the kinetic behaviour of bacterial oxidation of pyrite, particularly for gold recovery from refractory types of ores. It is reported that the oxidation of framboidal and euhedral pyrites are completely different. Framboidal pyrite has a granular and irregular surface structure and is more chemically reactive than the highly crystalline surface structure of euhedral pyrite. Hence, the rate of surface oxidation by Thiobacillus ferrooxidans microorganism is higher than the other pyrite forms [22].

Previous works in the literature have shown that the textural mineralogy of pyrite determines its surface characteristics and flotation behaviour in complex sulfide ores. Pyrite particles having a framboidal/altered texture are known to significantly affect pulp chemistry and adversely affect flotation performance. Therefore, the main objectives of this study were to demonstrate the influence of pyrite mineralogy on the flotation of copper ores, and to develop an alternative condition to improve performance. Two copper ore samples (Ore A and Ore B) having different textural/modal mineralogy and flotation characteristics were taken from different zones of the same ore deposit. Ore B contained framboidal pyrite and altered pyrite/marcasite, which is considered the main reason for the low flotation performance in both copper and pyrite flotation sections of the process plant. 


\section{Materials and Methods}

Representative samples were taken from the two ore types, named as Ore A and Ore $\mathrm{B}$, from a complex $\mathrm{Cu}-\mathrm{Zn}$ ore deposited located in northeast of Turkey. Both ore types were treated by flotation at a primary grind size of $80 \%$ passing $38 \mu \mathrm{m}$ to produce copper and pyrite concentrates. Production of a separate zinc concentrate was not considered feasible in the operation due to the highly variable zinc grade of the ore. Therefore, the zinc was recovered to the copper concentrate. Table 1 shows size-by-size assays of different major metals in the two ore samples ground to $\mathrm{d}_{80}: 38 \mu \mathrm{m}$. Ore A was a typical copper ore containing high amount of pyrite. On the other hand, Ore B contained significant amounts of $\mathrm{Zn}$ and $\mathrm{Pb}$, indicating its complex nature.

Table 1. Chemical composition of Ore A and Ore B on a size by assay basis.

\begin{tabular}{cccccccc}
\hline & Weight, $\%$ & $\mathbf{C u}, \%$ & $\mathbf{Z n}, \mathbf{\%}$ & $\mathbf{P b}, \mathbf{\%}$ & $\mathbf{F e}, \mathbf{\%}$ & $\mathbf{S}, \mathbf{\%}$ \\
\hline \multirow{4}{*}{ Ore A } & $+38 \mu \mathrm{m}$ & 22.30 & 2.09 & 0.10 & 0.04 & 45.44 & 51.24 \\
& $-38+20 \mu \mathrm{m}$ & 25.90 & 2.39 & 0.10 & 0.07 & 45.75 & 50.63 \\
& $-20+10 \mu \mathrm{m}$ & 49.02 & 2.99 & 0.19 & 0.10 & 44.98 & 47.20 \\
& $-10 \mu \mathrm{m}$ & 2.78 & 3.45 & 0.38 & 0.27 & 40.10 & 39.90 \\
& Head assays & 100.00 & 2.94 & 0.20 & 0.08 & 44.47 & 50.31 \\
\hline \multirow{2}{*}{ Ore B } & $+38 \mu \mathrm{m}$ & 20.89 & 0.84 & 2.75 & 0.60 & 33.27 & 38.54 \\
& $-38+20 \mu \mathrm{m}$ & 21.86 & 0.82 & 2.71 & 0.83 & 33.04 & 35.36 \\
& $-20+10 \mu \mathrm{m}$ & 51.26 & 1.60 & 3.97 & 1.20 & 26.94 & 31.20 \\
& $-10 \mu \mathrm{m}$ & 5.99 & 1.88 & 4.43 & 1.35 & 23.56 & 27.40 \\
& Head assays & 100.00 & 1.34 & 3.66 & 1.08 & 28.03 & 33.90 \\
\hline
\end{tabular}

BMA (Bulk Mineralogical Analysis) and PMA (Particle Mineral Analysis) characterization were performed on a size-by-size basis for both samples. Polished sections of $+38 \mu \mathrm{m},-38+20 \mu \mathrm{m}$, and $-20+10 \mu \mathrm{m}$ size fractions were prepared and analyzed using QemSCAN, which has an FEI Quanta 650F electron microscope equipped with a field-emission gun as an electron source. The $-10 \mu \mathrm{m}$ size fraction was not included in the mineralogical analysis because of the agglomeration of fine particles observed during preparation of the polished sections. For imaging and X-ray based microchemical analysis, the instrument is equipped with a four-quadrant, solid state back-scattered electron (BSE) detector and two Bruker XFlash 5030 detectors. The liberation criterion was selected as $90 \%$, which means any particle containing $90 \%$ and $100 \%$ by area of the mineral of interest is regarded as liberated. Particles that contain between $50 \%$ and $90 \%$ by area are referred to as middling/binary particles, while those containing less than $50 \%$ by area are referred to as locked particles.

In addition to quantitative mineralogical characterization, petrography analysis by transmitted and reflective light microscopy was performed to determine Fe sulfide speciation. The samples were prepared as $20 \times 40 \mathrm{~mm}$ polished thin sections and analyzed with a petrographic microscope under polarized transmitted and polarized reflected light. This analysis provides information about petrographic rock classification, microstructure of the samples, and the modal percentage of each mineral.

Ethylene diamine-tetra acetic acid disodium salt (EDTA) extraction tests were conducted to characterize surface oxidation of the sulfide minerals in both ore samples. A fraction (10 g) of dry ore was leached for $30 \mathrm{~min}$ in a $200 \mathrm{~mL}$ solution containing 3\% EDTA at $\mathrm{pH}$ 7.5. The pulp was filtrated, and the filtrate was assayed for $\mathrm{Cu}, \mathrm{Zn}, \mathrm{Fe}, \mathrm{Pb}$ using AAS. The results indicated that surface oxidation of the copper minerals and galena was higher in Ore B (Table 2).

Batch scale flotation tests were performed on both ore types and on a composite sample prepared from their blend to evaluate the effects of Fe sulfide forms on flotation. The flotation feed was ground to $\mathrm{d}_{80}: 38 \mu \mathrm{m}$ in a ball mill at $60 \% \mathrm{w} / \mathrm{w}$ pulp density. The flotation tests were carried out at $30 \%$ pulp density using a $4.5 \mathrm{~L}$ Denver flotation cell. In the flotation plant, a proprietary blend collector Kimfloat900 $(150 \mathrm{~g} / \mathrm{t})$, a thionocarbamate 
formulation, was used in the copper flotation circuit at $\mathrm{pH} 11.5-12$. The $\mathrm{pH}$ was kept constant at the target values by adding lime into the ball mill and flotation. A TPS meter was used to measure $\mathrm{pH}$ and Eh values during the flotation process. Following the copper flotation stage, an ether amine form collector, TomAmine $(100 \mathrm{~g} / \mathrm{t})$, was used as the collector for pyrite flotation at $\mathrm{pH} 11$. These flotation conditions were termed the Base Condition (BC) which is applied in the plant. Alternative collectors, diisobutyl phosphinate (Aerophine 3418A), sodium isopropyl xanthate (SIPX) and thionocarbamate (Aero 5100) were tested to improve copper flotation performance. Potassium amyl xanthate (KAX) was tested for pyrite flotation. Methyl isobutyl carbinol (MIBC) was used as the frother. Sodium sulfide $\left(\mathrm{Na}_{2} \mathrm{~S}\right)$ and sodium hydrosulfide (NaHS) were tested for surface cleaning of the tarnished minerals and framboidal pyrite, particularly for Ore B (Table 3).

Table 2. EDTA results for Ore A and B.

\begin{tabular}{ccccc}
\hline & \multicolumn{5}{c}{ Extractable Metal/Total Metal (\%) } \\
\cline { 2 - 5 } & $\mathbf{C u}$ & $\mathbf{F e}$ & $\mathbf{P b}$ & $\mathbf{Z n}$ \\
\hline Ore A & 1.67 & 0.11 & 44.90 & 4.51 \\
\hline Ore B & 3.69 & 0.09 & 72.70 & 0.86 \\
\hline
\end{tabular}

Table 3. Reagent scheme used in the flotation tests.

\begin{tabular}{cc}
\hline & $\begin{array}{c}\text { Kimfloat900 (used as base condition, BC) } \\
\text { Aero5100 } \\
\text { Collectors for copper flotation } \\
\text { Aerophine 3418A } \\
\text { SIPX }\end{array}$ \\
\hline Collectors for pyrite flotation & TomAmine (used as base condition, BC) \\
\hline Frother & $\mathrm{MIBC}$ \\
\hline Sulphidization agents for surface cleaning & $\mathrm{NaHS}, \mathrm{Na}_{2} \mathrm{~S}$ \\
\hline Depressant & $\mathrm{Na}-\mathrm{MBS}$ \\
\hline
\end{tabular}

\section{Results and Discussion}

\subsection{Modal/Particle Mineralogy and Fe Sulfide Identification}

Mineral distribution is given on a size-by-size basis for both ore samples in Table 4. The major sulfide minerals were pyrite/marcasite, chalcopyrite, sphalerite, and minor amount of galena. The Ore B sample contained significant amounts of barite as the nonsulfide gangue mineral. Pyrite/marcasite accounted for the major iron sulfide gang mineral together with the altered pyrite in both ore types.

Grain size and liberation characteristics of the sulfide minerals were completely different in the two ore samples. Both chalcopyrite and pyrite showed higher liberation in Ore A with values of more than $80 \%$ and $90 \%$, respectively (Table 5). Percentage of free particles decreased at $-20+10 \mu \mathrm{m}$ size fraction in both ore samples. This unexpected result was attributed to agglomeration problems during preparation of polished sections. Unlike Ore A, the sulfide minerals in Ore B were in the form of fine grains (Figure 1) and showed complex liberation characteristics. It was seen that in every size fraction, the grain size distribution was finer in Ore B, particularly for pyrite (Figure 1). The liberation value of chalcopyrite in Ore B was only $~ 15 \%$, and the chalcopyrite particles were mostly in the form of binary chalcopyrite/pyrite particles. The percentage of sphalerite was higher in Ore B and had a low degree of liberation, in the range of $18-33 \%$. A significant part of sphalerite was in the form of binary association with pyrite and barite. The pyrite particles in Ore A showed a considerably higher degree of liberation (91\%) than those in Ore B (57\%). The aggregate and inclusion-rich form of pyrite was also seen from binary association data. The back-scatter electron (BSE) images clearly showed that some of the pyrite in Ore B had a framboidal structure and the rest had an altered structure and marcasite (Figure 2). 
Table 4. Modal mineralogy of Ore A and Ore B on size-by-size basis.

\begin{tabular}{|c|c|c|c|c|c|c|}
\hline \multirow{2}{*}{ Minerals } & \multicolumn{3}{|c|}{ Ore A (\%) } & \multicolumn{3}{|c|}{ Ore B (\%) } \\
\hline & $+38 \mu \mathrm{m}$ & $-38+20 \mu \mathrm{m}$ & $-20+10 \mu \mathrm{m}$ & $+38 \mu \mathrm{m}$ & $-38+20 \mu \mathrm{m}$ & $-20+10 \mu \mathrm{m}$ \\
\hline Chalcopyrite & 5.96 & 6.54 & 7.33 & 1.29 & 1.16 & 1.68 \\
\hline Sphalerite & 0.08 & 0.07 & 0.19 & 3.99 & 3.96 & 4.35 \\
\hline Pyrite/Marcasite & 90.72 & 89.59 & 85.52 & 66.83 & 56.71 & 40.75 \\
\hline Galena & $<0.01$ & $<0.01$ & $<0.01$ & 0.67 & 0.94 & 0.37 \\
\hline Barite & 0.05 & 0.04 & 0.10 & 22.17 & 25.62 & 18.06 \\
\hline Quartz & 0.03 & 0.06 & 0.07 & 0.02 & 0.07 & 0.03 \\
\hline Biotite & 0.07 & 0.01 & $<0.01$ & 0.09 & 0.03 & $<0.01$ \\
\hline Pyrite-Altered/Aggregate & 2.85 & 3.45 & 6.43 & 2.59 & 7.46 & 17.47 \\
\hline Sulfide-Clay Mixed & 0.09 & 0.04 & 0.05 & 0.03 & 0.07 & 0.21 \\
\hline Sulfides-Barite Aggregates & 0.01 & 0.01 & 0.04 & 2.13 & 3.64 & 16.14 \\
\hline Others & 0.13 & 0.18 & 0.27 & 0.19 & 0.34 & 0.94 \\
\hline Total & 100.00 & 100.00 & 100.00 & 100.00 & 100.00 & 100.00 \\
\hline
\end{tabular}

Table 5. Size-by-size liberation of chalcopyrite and pyrite minerals in Ore A and Ore B.

\begin{tabular}{|c|c|c|c|c|c|c|c|c|c|}
\hline \multirow{2}{*}{ Chalcopyrite } & \multirow[b]{2}{*}{ Free } & \multicolumn{7}{|c|}{ Binary Association } & \multirow[b]{2}{*}{ Total } \\
\hline & & Pyrite & Sphalerite & Barite & Galena & Quartz & Aggregates & Other & \\
\hline Ore $A /+38 \mu \mathrm{m}$ & 80.53 & 17.80 & 0.21 & 0.17 & 0.00 & 0.00 & 0.07 & 1.23 & 100.00 \\
\hline Ore $A /-38+20 \mu \mathrm{m}$ & 82.81 & 15.63 & 0.17 & 0.23 & 0.00 & 0.00 & 0.19 & 0.97 & 100.00 \\
\hline Ore $A /-20+10 \mu \mathrm{m}$ & 56.21 & 38.05 & 0.25 & 0.27 & 0.01 & 0.00 & 3.96 & 1.25 & 100.00 \\
\hline Ore $B /+38 \mu \mathrm{m}$ & 5.72 & 50.37 & 7.52 & 7.34 & 0.21 & 0.00 & 0.08 & 28.76 & 100.00 \\
\hline Ore $B /-38+20 \mu \mathrm{m}$ & 15.13 & 39.33 & 8.18 & 16.62 & 0.11 & 0.00 & 0.82 & 19.82 & 100.00 \\
\hline Ore $B /-20+10 \mu \mathrm{m}$ & 13.89 & 34.49 & 6.56 & 9.28 & 0.08 & 0.06 & 7.00 & 28.63 & 100.00 \\
\hline \multirow{2}{*}{ Pyrite } & \multicolumn{8}{|c|}{ Binary Association } & \multirow[b]{2}{*}{ Total } \\
\hline & Free & Sphalerite & Barite & Galena & Chalcopyite & Quartz & Aggregates & Other & \\
\hline Ore $A /+38 \mu \mathrm{m}$ & 92.05 & 0.43 & 0.06 & 0.01 & 5.28 & 0.00 & 1.99 & 0.18 & 100.00 \\
\hline Ore A/ $-38+20 \mu \mathrm{m}$ & 91.18 & 0.40 & 0.03 & 0.00 & 5.25 & 0.01 & 2.79 & 0.34 & 100.00 \\
\hline Ore $A /-20+10 \mu \mathrm{m}$ & 81.74 & 0.49 & 0.25 & 0.01 & 11.59 & 0.00 & 5.14 & 0.77 & 100.00 \\
\hline Ore $B /+38 \mu \mathrm{m}$ & 77.01 & 10.67 & 7.30 & 0.18 & 2.07 & 0.00 & 2.03 & 0.75 & 100.00 \\
\hline Ore $B /-38+20 \mu \mathrm{m}$ & 51.09 & 7.55 & 6.45 & 0.10 & 2.27 & 0.00 & 31.44 & 1.09 & 100.00 \\
\hline Ore $B /-20+10 \mu \mathrm{m}$ & 44.39 & 8.48 & 14.37 & 0.24 & 2.94 & 0.01 & 15.87 & 13.71 & 100.00 \\
\hline
\end{tabular}

The framboidal structure is very well defined by Wilkin and Barnes [10], and is considered to form as a result of consecutive processes such as nucleation and the growth of initial iron monosulfide microcrystals, reaction of the microcrystals to greigite, framboid growth of microcrystals and replacement of these framboids by pyrite. Since it is very difficult to quantify Fe sulfide species with QemSCAN, petrography analysis was performed using a transmitted and reflective light microscope on both ore types. According to the analysis of thin sections of Ore B, $\sim 1.5 \%$ of pyrite particles were defined as framboidal with a size range of $0.01-5 \mathrm{~mm}$. The marcasite particles were observed as alteration and weathering minerals in an amount of $2-3 \%$, with a size range up to $0.3 \mathrm{~mm}$. In some fragments, the pyrite crystals were immersed within a second generation of pyrite. In other fragments, the pyrite was intergrown with sphalerite (Figure 3a), and the two minerals formed crus- 
tiform intergrowths. Although only $1.5 \%$ of the pyrite appeared in framboidal form, the rest of the pyrite was found to exist with spongy inclusions, forming aggregates and an anhedral crystal form (Figure 3b). These aggregates tended to form rounded framboidal aggregates, which were clearly distinguished by the subhedral and inclusion-free crystals or the inclusion-poor interstitial aggregates of pyrite.

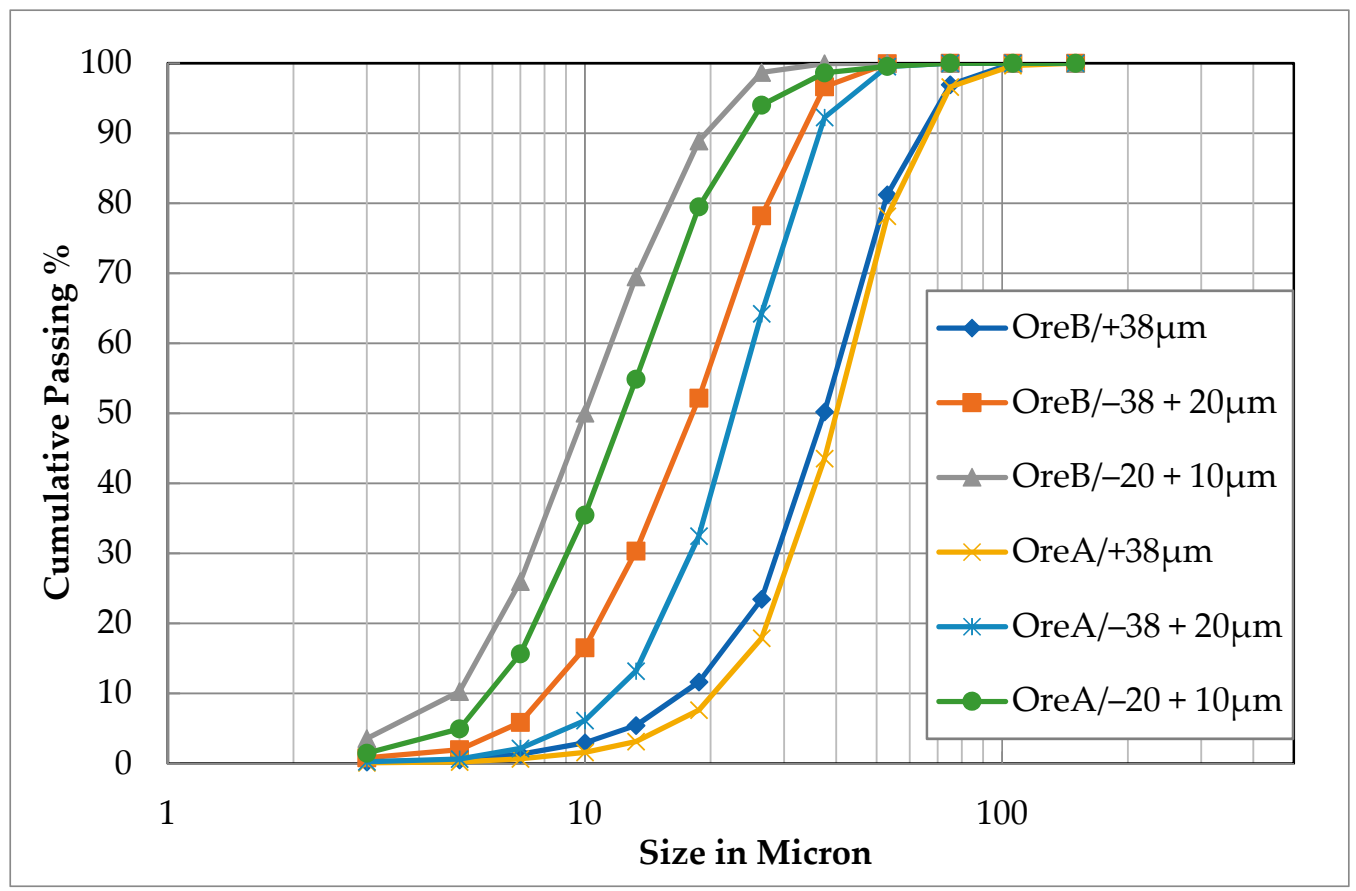

Figure 1. Grain size distributions of pyrite in size fractions of Ore A and B.
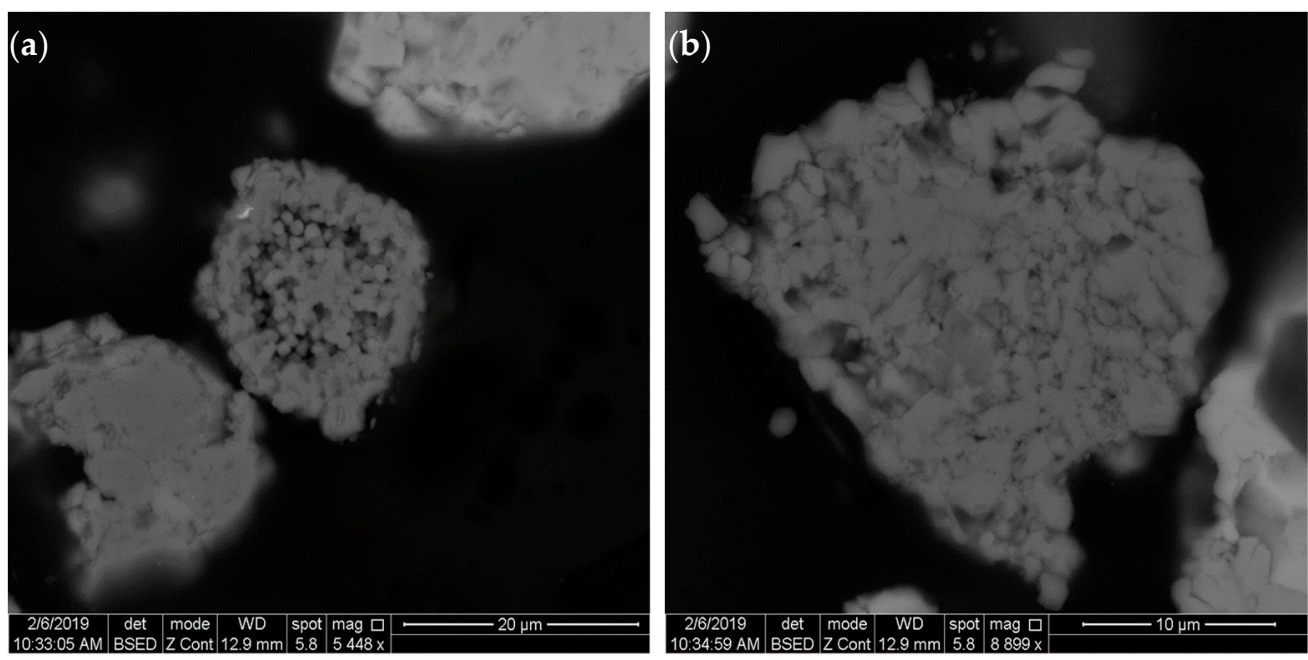

Figure 2. Framboidal pyrite (a) and altered pyrite/marcasite (b) from Ore B.

In Ore A, pyrite dominated the composition of the fragments and formed quasimassive aggregates intergrown with subordinate crystals of chalcopyrite and marcasite (Figure 4). Pyrite accounted for $95-97 \%$ of modal mineralogy ranging in a size of $0.01 \mathrm{~mm}$ to massive. The amount of marcasite was $1.5 \%$ and found as fine-to medium-grained anhedral crystals which were heterogeneously dispersed in pyrite. 

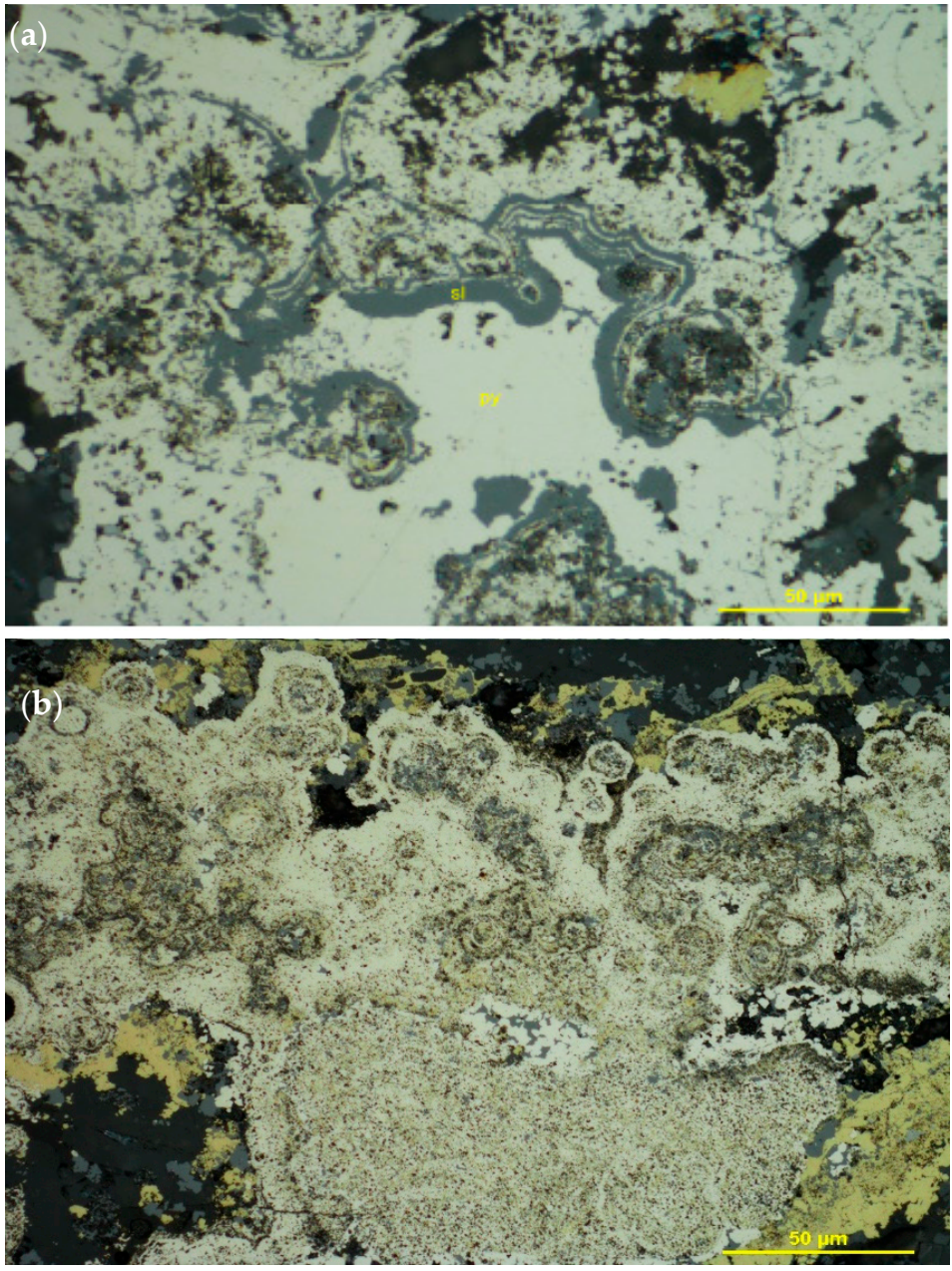

Figure 3. Very fine-grained crystals of pyrite (py) are intergrown with the sphalerite (sl) and define crustiform and layered intergrowths (a). Porous and spongy aggregates of pyrite define rounded framboidal aggregates and irregularly shaped domains associated with subordinate inclusion-free interstitial pyrite (b) from Ore B.

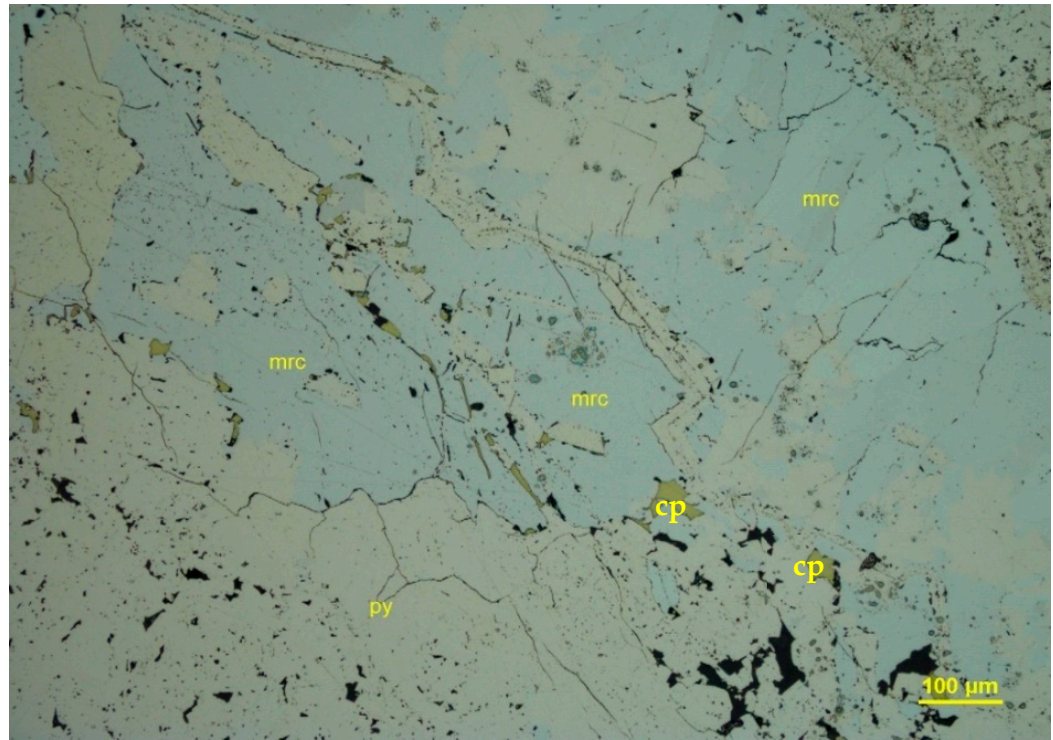

Figure 4. Pyrite (py) hosts medium-grained crystals of marcasite (mrc) and fine-grained crystals of chalcopyrite (cp) from Ore A. 


\subsection{Flotation Behavior of Ore $A$}

Mineralogical investigation and chemical assays showed that Ore A had a relatively simpler ore texture and low Zn content. The test performed at the Base Condition (BC) produced a copper rougher concentrate at $71 \%$ copper recovery (Table 6). Pyrite flotation was applied on the copper rougher tail using TomAmine at $\mathrm{pH}$ 10.5-11. A pyrite concentrate was produced assaying $50 \% \mathrm{~S}$ at $68 \%$ recovery.

Table 6. Flotation behavior of Ore A under the Base Condition.

\begin{tabular}{cccccccc}
\hline & \multicolumn{4}{c}{ Cu Rougher Concentrate } & \multicolumn{2}{c}{ Pyrite Concentrate } \\
\hline \multirow{2}{*}{$\begin{array}{c}\text { Cu Rougher } \\
\text { Concentrate }\end{array}$} & Mass & \multicolumn{2}{c}{ Grade $(\%)$} & Recovery (\%) & Grade (\%) & Recovery (\%) \\
\cline { 3 - 8 } & Pull, $\%$ & $\mathrm{Cu}$ & $\mathrm{Zn}$ & $\mathrm{Cu}$ & $\mathrm{Zn}$ & $\mathrm{S}$ & $\mathrm{S}$ \\
\hline Base Condition & 13.69 & 13.99 & 0.74 & 70.98 & 48.93 & 50.31 & 68.22 \\
\hline
\end{tabular}

\subsection{Flotation Behavior of Ore B}

Chemical and mineralogical characteristics of Ore B were completely different from those of Ore A. Rougher kinetic tests were conducted to determine its flotation response at the Base Condition and investigate effects of alternative flotation chemistry (collector type, sulphidization for surface cleaning, use of MBS as depressant) and particle size. In the $\mathrm{BC}$ test, stage addition of $150 \mathrm{~g} / \mathrm{t}$ Kimfloat 900 collector was applied at about $\mathrm{pH} 12$. A combined copper rougher concentrate was produced assaying $2.4 \% \mathrm{Cu}$ at $5.1 \%$ recovery. Following the copper flotation stage, pyrite rougher flotation was performed at the same $\mathrm{pH}$ using $100 \mathrm{~g} / \mathrm{t}$ TomAmine as collector. A pyrite rougher concentrate was produced assaying $28 \% \mathrm{~S}$ at $25 \%$ recovery and $29 \%$ mass pull. These results show that the performance of both copper and pyrite flotation stages were considerably lower than those obtained with Ore A (Table 6).

Alternative flotation conditions were investigated to improve the flotation performance of Ore B. In one of the tests, the collector was added at the milling stage. Aero5100 $(120 \mathrm{~g} / \mathrm{t})$ and a mixture of Aero3418A $+\operatorname{SIPX}(90+90 \mathrm{~g} / \mathrm{t})$ were used as alternative collectors. Figure 5 shows that the copper recovery increased to $67 \%$ at $31 \%$ mass pull using a mixture of Aero3418A + SIPX.

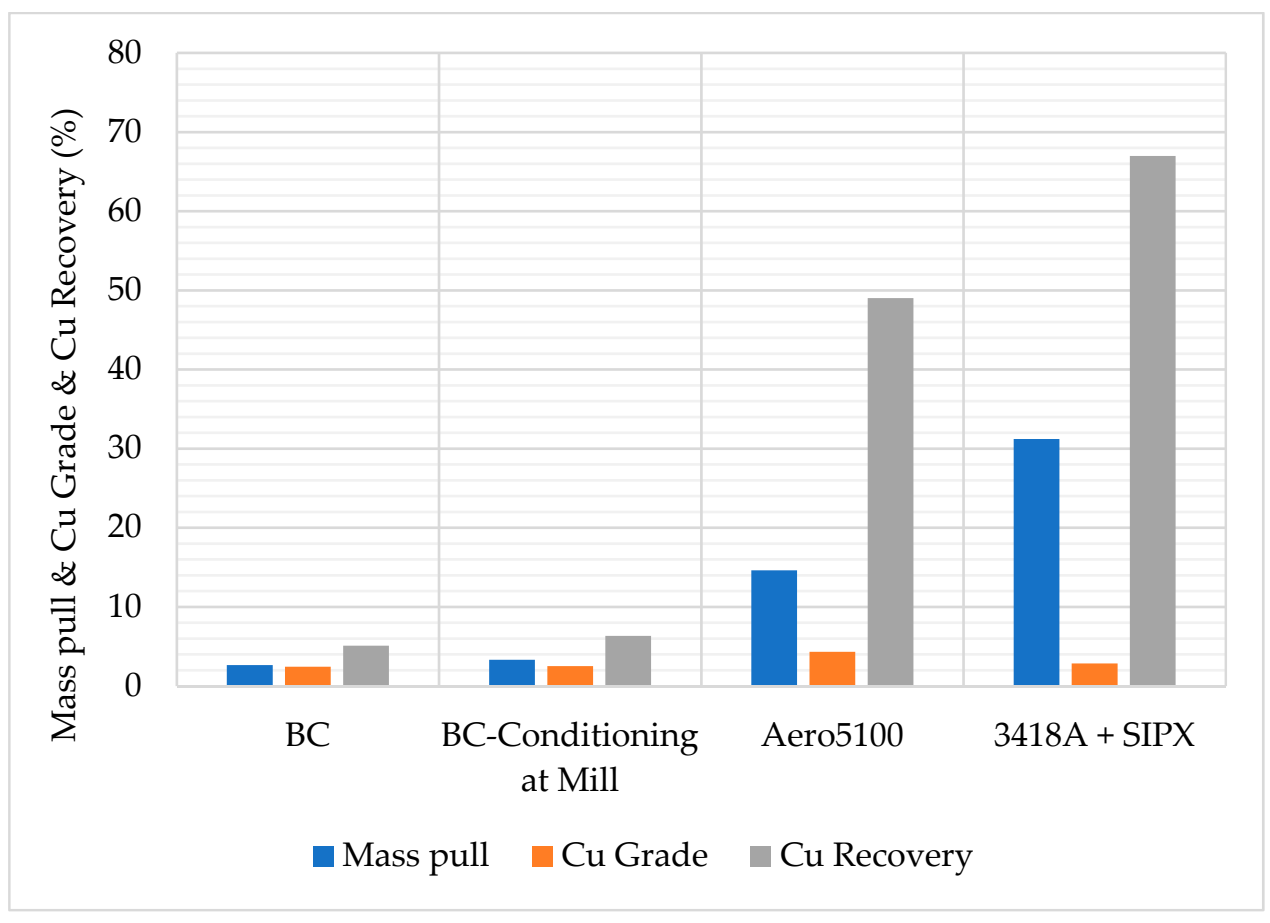

Figure 5. Effect of different reagent applications on the rougher flotation performance of Ore B. 


\subsubsection{Effects of Surface Cleaning}

Ore B contained altered marcasite and framboidal pyrite, which oxidizes faster than pyrite. Therefore, $\mathrm{Na}_{2} \mathrm{~S}$ and $\mathrm{NaHS}$ were tested as sulphidization agents in order to remove the surface oxidation species from mineral surfaces and minimize further oxidation during flotation $[9,23]$. The mixture of Aerophine 3418A + SIPX was used as a collector in these tests at natural $\mathrm{pH}$ ( $\mathrm{pH}$ 8.8-9.6). $\mathrm{Na}_{2} \mathrm{~S}$ was tested in $500 \mathrm{~g} / \mathrm{t}, 1000 \mathrm{~g} / \mathrm{t}$ and $1500 \mathrm{~g} / \mathrm{t}$ dosages and added at the grinding stage. Addition of $\mathrm{Na}_{2} \mathrm{~S}$ decreased the pulp Eh as a function of reagent dosage down to the lowest value $-150 \mathrm{mV}(\mathrm{Ag} / \mathrm{AgCl})$ after grinding. Pre-aeration ( $5 \mathrm{~min}$ ) was applied prior to collector addition to increase the dissolved oxygen content and Eh to slightly positive values ( -2 to $60 \mathrm{mV}$ ).

The results showed that sulfidization improved the flotation performance and the $\mathrm{Cu}$ recovery increased to $75 \%$ at a $1000 \mathrm{~g} / \mathrm{t} \mathrm{Na} \mathrm{Na}_{2} \mathrm{~S}$ dosage. Increasing $\mathrm{Na}_{2} \mathrm{~S}$ dosage to $1500 \mathrm{~g} / \mathrm{t}$ did not further improve the copper recovery (Figure 6). NaHS was also tested as an alternative sulfidizing reagent to $\mathrm{Na}_{2} \mathrm{~S}$ at a $1000 \mathrm{~g} / \mathrm{t}$ dosage. Similar recovery values were obtained using both $\mathrm{Na}_{2} \mathrm{~S}$ and NaHS, and a $1000 \mathrm{~g} / \mathrm{t}$ dosage was required for an effective surface cleaning.

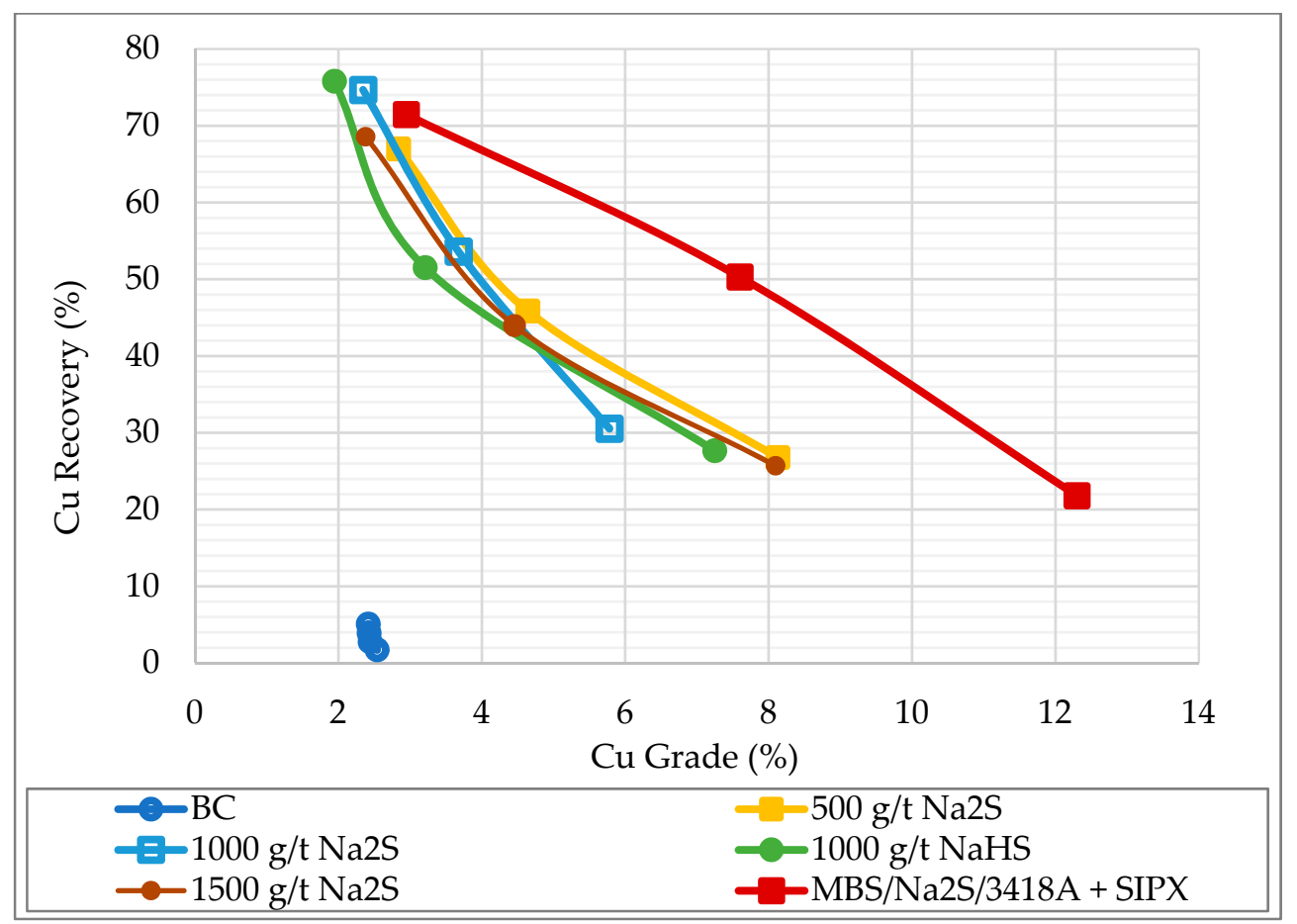

Figure 6. Effect of sulphidization and MBS addition on Cu recovery-grade of Ore B.

\subsubsection{Effects of MBS Addition}

Effective depression of pyrite during the copper rougher flotation stage directly affects the quality of both the copper rougher concentrate and the pyrite concentrate. It is well known that sulfoxy reagents such as sodium metabisulfite are widely used as for pyrite depression as they enhance formation of hydrated iron oxide layers on pyrite and suppress the adsorption of xanthate by reducing the mixed potential $[19,24]$. For this purpose, Nametabisulfite (MBS) addition in the grinding stage was tested. The pulp potential (Eh) was monitored and recorded as $-198 \mathrm{mV}$ and $40 \mathrm{mV}$ just after the grinding and pre-aeration stages, respectively. It was found that pyrite could be effectively depressed at $3000 \mathrm{~g} / \mathrm{t}$ dosage and $\mathrm{pH}$ 6.5. Figure 6 shows that the highest copper grade values were obtained in the presence of MBS because of the effective depression of pyrite. 


\subsection{Flotation Behavior of Mix Ore}

During plant scale operation, it may not be possible to always process Ore B and Ore A separately. A blend of these two ore types could be treated in the flotation plant. Therefore, effects of blending Ore B with Ore A were investigated under two different flotation conditions. The two ore types were blended at equal proportions for these tests according to the recommendations from the mine site.

The negative effect of Ore B on flotation performance was clearly seen in the mixture. The copper recovery in Ore A was $71 \%$ under the base flotation conditions (Table 6), and dropped to $22 \%$ when it was mixed with Ore B. Therefore, the flotation conditions were changed, and the optimum conditions developed for Ore B were applied to the blend ore. Use of $\mathrm{Na}_{2} \mathrm{~S}$ and MBS was tested at various dosages. The best results were obtained at $3000 \mathrm{~g} / \mathrm{t}$ of MBS and $1000 \mathrm{~g} / \mathrm{t} \mathrm{Na}_{2} \mathrm{~S}$ added at the grinding stage with a mixture of Aero3418A + SIPX as collector in the copper flotation stage and with $200 \mathrm{~g} / \mathrm{t} \mathrm{KAX}$ in pyrite flotation. Table 7 shows that the copper grade and recoveries were significantly improved using the optimum flotation conditions developed for Ore B.

Table 7. Results of the open cleaner flotation test performed using a blend of Ore A:Ore B (50:50) under optimum flotation conditions (3000 g/t MBS, $1000 \mathrm{~g} / \mathrm{t} \mathrm{Na} 2 \mathrm{~S}, 180 \mathrm{~g} / \mathrm{t} 3418 \mathrm{~A}+\mathrm{SIPX}$ in copper flotation and $200 \mathrm{~g} / \mathrm{t} \mathrm{KAX}$ in pyrite flotation.

\begin{tabular}{cccccc}
\hline \multirow{2}{*}{ Stream } & Mass Pull, $\%$ & \multicolumn{2}{c}{ Grade, $\%$} & \multicolumn{2}{c}{ Recovery, \% } \\
\cline { 3 - 6 } & & $\mathbf{C u}$ & $\mathbf{S}$ & $\mathbf{C u}$ & $\mathbf{S}$ \\
\hline Cu Rougher Concentrate & 12.88 & 11.04 & 37.67 & 72.28 & 12.24 \\
Cu Concentrate & 2.11 & 32.59 & 28.38 & 34.94 & 1.51 \\
Pyrite Rougher Concentrate & 73.63 & 0.71 & 45.84 & 26.56 & 85.16 \\
Pyrite Concentrate & 59.82 & 0.65 & 48.51 & 19.76 & 73.22 \\
Tail & 13.49 & 0.17 & 7.63 & 1.16 & 2.60 \\
Feed & & & & 100.00 & 100.00 \\
\hline
\end{tabular}

Effects of alternative conditions on flotation performance of the two ore types and their mixture were evaluated based on the results of open cleaner flotation tests. In these tests, the influence of recirculating cleaner flotation tailing was not taken into consideration. Therefore, simulation studies were performed using JKSimFloat software to estimate metallurgical performance of closed-circuit operation. In the simulation studies, first mineral assays and stage recoveries were determined by mass balance of the open cleaner flotation tests. Stage recoveries of the minerals were assumed constant in each flotation stage during simulation.

Table 8 shows the results of the simulation studies for Ore A, Ore B and their mixture under optimum flotation conditions. A copper concentrate could be produced from Ore A with approximately $28 \% \mathrm{Cu}$ grade at $76 \%$ recovery. Use of $\mathrm{Na}_{2} \mathrm{~S}$ and $\mathrm{MBS}$ improved flotation response of Ore $\mathrm{B}$ to some extent, and a copper concentrate was produced assaying $21.62 \% \mathrm{Cu}$ at $52.36 \%$ recovery. The copper flotation performance of the mixed ore samples was just between the two ores, as expected.

Table 8. Flotation performance of Ore A, Ore B and a mixture of the two ores under optimum flotation conditions applied on each ore type.

\begin{tabular}{ccccccc}
\hline & \multicolumn{3}{c}{ Copper Concentrate } & \multicolumn{3}{c}{ Pyrite Concentrate } \\
\cline { 2 - 7 } & $\begin{array}{c}\text { Mass Pull } \\
\mathbf{( \% )}\end{array}$ & Cu \% & $\begin{array}{c}\text { Cu Recovery } \\
\mathbf{( \% )}\end{array}$ & $\begin{array}{c}\text { Mass Pull } \\
\mathbf{( \% )}\end{array}$ & S \% & $\begin{array}{c}\text { S Recovery } \\
\mathbf{( \% )}\end{array}$ \\
\hline Ore A & 7.42 & 27.74 & 76.42 & 92.58 & 50.79 & 95.05 \\
Ore B & 2.93 & 21.62 & 52.36 & 63.98 & 44.26 & 92.78 \\
Mix & 4.02 & 31.49 & 65.46 & 77.93 & 49.17 & 93.06 \\
\hline
\end{tabular}


Pyrite flotation was conducted following the copper flotation section. Table 8 shows that saleable grade pyrite concentrate could be produced from the three samples at high recoveries.

Surface cleaning by $\mathrm{Na}_{2} \mathrm{~S}$ and depression of pyrite by MBS mitigated the negative effect of framboidal, spongy, altered pyrite from Ore B. Following copper flotation, a high-grade pyrite concentrate could be produced from all ore samples.

\section{Conclusions}

Two different ore types, Ore A and Ore B from the same ore deposit, were used to investigate effects of pyrite mineralogy on the performance of the copper and pyrite flotation stages.

Mineralogical characterization showed that Ore A did not contain framboidal and altered pyrite. High grade copper concentrates could be produced at acceptable recoveries at the base conditions applied in the flotation plant.

Ore B contained framboidal and altered pyrite/marcasite and did not respond to the base flotation conditions. This was attributed to the framboidal and spongy, inclusion-rich, altered pyrite content and relatively high surface oxidation of altered marcasite particles.

$\mathrm{Na}_{2} \mathrm{~S}$ and $\mathrm{NaHS}$ were used for surface cleaning purpose of the sulfide minerals and control of the pulp redox potential. Both reagents improved the copper flotation performance. The copper recovery increased from about $5 \%$ up to $52 \%$.

Blending Ore B with Ore A reduced the overall flotation performance under the base conditions. However, the flotation could be restored after sulphidization, i.e., using the optimum conditions developed for the problematic Ore B. Flotation performances of the new mix samples with different mass contents of Ore A and B can be investigated in future work.

The results of this study showed clearly the importance of process mineralogy for identification of the problematic components for flotation. Framboidal/altered pyrite particles were the main source of the problem in this case. An alternative flotation chemistry was developed based on sulphidization and the use of selective copper collectors and improved the flotation performance successfully.

Author Contributions: Conceptualization, İ.B.C. and Z.E.; methodology, İ.B.C., S.Ö. and Z.E.; validation, İ.B.C., S.Ö. and Z.E.; formal analysis, S.Ö.; investigation, İ.B.C. and Z.E.; resources, Z.E.; data curation, S.Ö. and İ.B.C.; writing—original draft preparation, İ.B.C.; writing-review and editing, Z.E. and S.Ö.; visualization, İ.B.C. and Z.E.; supervision, Z.E.; project administration, Z.E.; funding acquisition, Z.E. All authors have read and agreed to the published version of the manuscript.

Funding: This research received no external funding.

Acknowledgments: The authors would like to acknowledge the staff of ETI Copper Plant for providing the samples and their technical support.

Conflicts of Interest: The authors declare no conflict of interest.

\section{References}

1. Chandra, A.P.; Gerson, A.R. The mechanisms of pyrite oxidation and leaching: A fundamental perspective. Surf. Sci. Rep. 2010, 65, 293-315. [CrossRef]

2. Xian, Y.; Wen, S.; Chen, X.; Deng, J.; Liu, J. Effect of lattice defects on the electronic structures and floatability of pyrites. Int. J. Miner. Metall. Mater. 2012, 19, 1069. [CrossRef]

3. Anthony, J.W.; Bideaux, R.A.; Bladh, K.W.; Nichols, M.C. Pyrite. In Handbook of Mineralogy; Elements, Sulfides, Sulfosalts; Mineralogical Society of America: Chantilly, VA, USA, 1990; Volume I, ISBN 978-0962209734.

4. Bayraktar, I.; Can, N.M.; Ekmekçi, Z. Effect of genesis on wetting behaviour of pyrite surfaces. In Innovations in Mineral and Coal Processing; Balkema: Rotterdam, The Netherlands, 1998; pp. 119-124.

5. Barker, G.J.; Gerson, A.R.; Menuge, J.F. The impact of iron sulfide on lead recovery at the giant Navan $\mathrm{Zn}-\mathrm{Pb}$ orebody, Ireland. Int. J. Miner. Process. 2014, 128, 16-24. [CrossRef]

6. Zhao, C.; Huang, D.; Chen, J.; Li, Y.; Chen, Y.; Li, W. The interaction of cyanide with pyrite, marcasite and pyrrhotite. Miner. Eng. 2016, 95, 131-137. [CrossRef] 
7. Wiersma, C.L.; Rimstidt, J.D. Rates of reaction of pyrite and marcasite with ferric iron at pH 2. Geochim. Cosmochim. Acta 1984, 48, 85-92. [CrossRef]

8. Butler, I.B.; Rickard, D. Framboidal pyrite formation via the oxidation of iron (II) monosulfide by hydrogen sulphide. Geochim. Cosmochim. Acta 2000, 64, 2665-2672. [CrossRef]

9. Bulatovic, S.M. Handbook of Flotation Reagents, Chemistry, Theory and Practice, Flotation of Sulphide Ores; Elsevier Science \& Technology Books: Amsterdam, The Netherlands, 2007; p. 443.

10. Wilkin, R.T.; Barnes, H.L. Formation processes of framboidal pyrite. Geochim. Cosmochim. Acta 1997, 61, 323-339. [CrossRef]

11. Dana, J.D.; Hurlbut, C.S.; Klein, C. Manual of Mineralogy (After James D. Dana); Wiley: New York, NY, USA, 1977.

12. Uhlig, I.; Szargan, R.; Nesbitt, H.W.; Laajalehto, K. Surface states and reactivity of pyrite and marcasite. Appl. Surf. Sci. 2001, 179, 222-229. [CrossRef]

13. Pugh, C.E.; Hossner, L.R.; Dixon, J.B. Oxidation rate of iron sulfides as affected by surface area, morphology, oxygen concentration, and autotrophic bacteria. Soil Sci. 1984, 137, 309-314. [CrossRef]

14. Simmons, G.L. Flotation of Auriferous Pyrite Using Santa Fe Pacific Gold's $N_{2}$ Tec Flotation Process; SME Annual Meeting: Denver, CO, USA, 1997; Preprint 97-27.

15. Miller, J.D.; Du Plessis, R.; Kotylar, D.G.; Zhu, X.; Simmons, G.L. The low-potential hydrophobic state of pyrite in amyl xanthate flotation with nitrogen. Int. J. Miner. Process. 2002, 67, 1-15. [CrossRef]

16. Chandra, A.P.; Gerson, A.R. A review of the fundamental studies of the copper activation mechanisms for selective flotation of the sulfide minerals, sphalerite and pyrite. Adv. Colloid Interface Sci. 2009, 145, 97-110. [CrossRef] [PubMed]

17. Peng, Y.; Grano, S.; Fornasiero, D.; Ralston, J. Control of grinding conditions in the flotation of galena and its separation from pyrite. Int. J. Miner. Process. 2003, 70, 67-82. [CrossRef]

18. Sui, C.C.; Brienne, S.H.R.; Xu, Z.; Finch, J.A. Xanthate adsorption on Pb contaminated pyrite. Int. J. Miner. Process. 1997, 49, 207-221. [CrossRef]

19. Moslemi, H.; Gharabaghi, M. A review on electrochemical behavior of pyrite in the froth flotation process. J. Ind. Eng. Chem. 2017, 47, 1-18. [CrossRef]

20. Owusu, C.; Abreu, S.B.; Skinner, W.; Addai-Mensah, J.; Zanin, M. The influence of pyrite content on the flotation of chalcopyrite/pyrite mixtures. Miner. Eng. 2014, 55, 87-95. [CrossRef]

21. Petruk, W. Applied mineralogy to related gold. In Applied Mineralogy in the Mining Industry; Elsevier: Amsterdam, The Netherlands, 2000; Chapter 6; p. 287.

22. Boon, M.; Brasser, H.J.; Hansford, G.S.; Heijnen, J.J. Comparison of the oxidation kinetics of different pyrites in the presence of Thiobacillus ferrooxidans or Leptospirillum ferrooxidans. Hydrometallurgy 1999, 53, 57-72. [CrossRef]

23. Mu, Y.; Peng, Y.; Lauten, R.A. The depression of pyrite in selective flotation by different reagent systems-A Literature review. Miner. Eng. 2016, 96-97, 143-156. [CrossRef]

24. Bulut, G.; Ceylan, A.; Soylu, B.; Goktepe, F. Role of starch and metabisulphite on pure pyrite and pyritic copper ore flotation. Physicochem. Probl. Miner. Process. 2011, 48, 39-48. 